\title{
OPTIMALISASI PENGELOLAAN ASUHAN KEPERAWATAN DI INSTALASI RAWAT JALAN RUMAH SAKIT X
}

\author{
Meylona Verawaty Zendrato ${ }^{1, *}$, Rr. Tutik Sri Hariyati ${ }^{2}$ \\ ${ }^{1}$ Kepemimpinan dan Manajemen Keperawatan, \\ Universitas Indonesia, Depok,16424, Indonesia \\ ${ }^{2}$ Departemen Keperawatan dan Dasar Keperawatan, \\ Universitas Indonesia, Depok, 16424, Indonesia \\ *) E-mail: meylona89@gmail.com
}

Diterima: Juni 2017, diterbitkan: Agustus 2017

\begin{abstract}
ABSTRAK
Kualitas asuhan keperawatan menjadi elemen kunci mutu pelayanan di rumah sakit. Fenomena yang terjadi di instalasi rawat jalan ialah pemberian asuhan keperawatan yang sangat minim. Tujuan penelitian: mengoptimalkan pengelolaan asuhan keperawatan di instalasi rawat jalan. Metode: Metode yang digunakan studi pilot, identifikasi masalah dengan teknik wawancara terstruktur, observasi, dan pengisian kuesioner kepada 28 perawat. Analisis masalah dilakukan dengan metode fish bone, pemecahan masalah menggunakan metode plan, do, check, action. Hasil: Terjadi peningkatan pengetahuan perawat terhadap proses asuhan keperawatan sebelum $(17,80 \%)$, sesudah implementasi $(82,3 \%)$, dan didapati empat faktor yang memengaruhi pemberian asuhan di instalasi rawat jalan, yaitu sumber daya manusia, sistem kerja yang jelas antarbagian, dokumentasi manual di luar keperawatan, dan fasilitas dan sarana yang kurang memadai. Diskusi: pengelolaan asuhan keperawatan membutuhkan dukungan manajemen. Kesimpulan: sebaiknya manajer melakukan perencanaan untuk peningkatan kualitas asuhan keperawatan melalui pengarahan pelayanan kepada visi rumah sakit, peningkatan pendidikan, peningkatan motivasi, dan berkoordinasi dalam pengadaan fasilitas dan sistem layanan guna optimalisasi pengelolaan asuhan keperawatan.
\end{abstract}

Kata kunci: asuhan keperawatan, pengelolaan, rawat jalan.

\section{OPTIMIZATION OF NURSING CARE MANAGEMENT AT OUTPATIENT INSTALLATION OF $X$ HOSPITAL}

\section{Abstract}

The quality of nursing care is a key element of hospital service quality. A phenomenon that occurs in outpatient care is providing nursing care at the minimum. Objective: To optimize the nursing care management $t$ outpatient installation. Methods: This study employed pilot study, identifying problem using structured interview technique, observation, and filling out questionnaires to 28 nurses. Problems were analyzed using fish bone and solved using plan, do, check, action method. Results: There was an increase in nurses' knowledge about the process of nursing care before (17.80\%) and after the implementation (82.3\%), and there were 4 factors that affected the provision of care in outpatient installation, namely human resources, a clear job system between departments, manual documentation beyond nursing, and inadequate facilities and infrastructure. Discussion: Nursing care management requires support from the management. Conclusion: Managers should plan on increasing the quality of nursing care by directing services to the vision of the hospital, improving education, increasing motivation, and coordinating in the procurement of facilities and service systems in order to optimize the nursing care management.

Keywords: nursing care, management, outpatient 


\section{LATAR BELAKANG}

Rumah sakit merupakan salah satu bentuk organisasi pelayanan kesehatan yang memberikan pelayanan kesehatan yang komprehensif mencakup aspek promotif, preventif, kuratif, dan rehabilitatif bagi seluruh lapisan masyarakat. Dalam rangka menjaga dan meningkatkan mutu pelayanan, salah satu aspek yang perlu mendapat perhatian ialah kualitas pelayanan keperawatan. Keperawatan sebagai salah satu bentuk pelayanan profesional merupakan bagian integral yang tidak dapat dipisahkan dari upaya pelayanan kesehatan secara keseluruhan. Keperawatan sering dikatakan sebagai tulang punggung dalam fasilitas kesehatan karena proporsi perawat yang mayoritas dibandingkan dengan tenaga kesehatan lainnya dan sangat menentukan gambaran kualitas pelayanan kesehatan (Kumari \& De, 2015). Hal ini didukung dengan melihat proporsi tenaga keperawatan, waktu perawat berinteraksi penuh selama 24 jam kepada pasien, dan akan menjadi salah satu faktor penentu baik buruknya mutu dan citra rumah sakit (Westbrook et al., 2011; Hagos et al., 2014).

Pada pelayanan keperawatan, manajemen asuhan sangat diperlukan. Manajemen asuhan yang dilakukan seorang manajer keperawatan mempunyai pengaruh paling kuat dalam keberlangsungan keperawatan di pelayanan kesehatan (Marquis \& Huston, 2012). Proses manajemen dimulai dari perencanaan, pengorganisasian, ketenagaan, pengarahan, dan pengendalian terhadap faktor sumber daya manusia, keuangan, material, metode, dan fasilitas (Marquis \& Huston, 2015). Manajer keperawatan akan memengaruhi kinerja staf keperawatan, menciptakan lingkungan kerja kondusif, dan akan berdampak terhadap keselamatan pasien, keberlangsungan organisasi, dan kualitas asuhan keperawatan (Manion, 2014; Miltner et al., 2015). Perawat dalam melaksanakan pelayananannya menggunakan pendekatan asuhan keperawatan yang bertujuan untuk meningkatkan derajat kesehatan pasien dan keluarga dan memberikan perawatan yang profesional. Dalam memberikan asuhan keperawatan, perawat menggunakan proses keperawatan dengan lima tahapan karena dengan menggunakan proses keperawatan, asuhan menjadi komprehensif (Hariyati, 2014).

Proses keperawatan merupakan metode sistematis untuk menilai, mendiagnosis, merencanakan, melaksanakan dan evaluasi keadaan pasien dalam keadaan sehat maupun sakit sehingga menjadi dasar pemecahaan secara ilmiah, dan menjadi dasar dalam praktik keperawatan (Baraki et al., 2017). Pengelolaan yang dilakukan penting juga diperlukan untuk efektivitas kolaborasi kemajuan pasien dan mencegah perburukan kondisi pasien (Baraki et al.., 2017).

Rumah Sakit X merupakan salah satu rumah sakit pemerintah yang berdiri sejak 2014. RS X berupaya meningkatkan kualitas pelayanan dengan mengikuti standar ISO dan akreditasi versi 2012 yang direncanakan Desember 2017. Saat ini RS X berupaya meningkatkan kualiats pelayanan sesuai dengan visi misi RS dengan mengoptimalkan fasilitas yang ada baik rawat inap dan rawat jalan. Pelayanan rawat jalan RS X merupakan pelayanan di rumah sakit yang diberikan kepada pasien dengan kasus diagnosis yang masih bisa ditangani tanpa memerlukan perawatan dan pasien paska perawatan sebagai kontrol kemajuan dari penyembuhan atas penyakit yang diderita oleh pasien tersebut. Rawat jalan yang merupakan bagian pelayanan rumah sakit dengan akses pemberian pelayanan singkat 
\pm 15 menit setiap pasien (Divisi Pelayanan Medik dan Keperawatan, 2016) dan terdiri atas 28 poliklinik dan berbagai spesialistik dengan pelayanan dilaksanakan pada pagi dan sore hari. Kunjungan dapat mencapai 1.000 kunjungan/hari.

Pemberian asuhan keperawatan di instalasi rawat jalan kurang optimal. Hal ini didukung oleh penjelasan Kepala Seksi Asuhan Keperawatan RS X yang menyatakan bahwa jarang sekali perawat memberikan asuhan keperawatan dengan pendekatan profesional menggunakan lima proses keperawatan yang terintegrasi di instalasi rawat jalan. Perawat tidak menjalankan peran pemberi asuhan, konselor, pendidik, kolaborator di instalasi rawat jalan dan dilihat dari hasil pendokumentasian asuhan keperawatan juga sangat minim dalam pelaksanaan hingga evaluasi. Kondisi ini juga dipengaruhi oleh fasilitas ruangan poliklinik yang terbatas, budaya pendampingan dokter, sistem rekam medis yang belum optimal, pelaksanaan tugas yang belum sesuai dengan uraian terlampir, prosedur operasional pemberian asuhan yang tidak tersedia, dan pendokumentasian keperawatan yang belum dilakukan dengan baik.

Terdapat berbagai hal yang perlu dikelola dalam menciptakan pemberian asuhan keperawatan yang optimal. Pengelolaan yang dilakukan seharusnya dimulai sejak pasien datang ke rawat jalan hingga akhirnya pasien pulang ke rumah, ke rawat inap, maupun dirujuk ke fasilitas kesehatan/penunjang lainnya. Jika ditinjau dari alur pelayanan rawat jalan, perawat memiliki peran dalam memberikan asuhan keperawatan dimulai dari pengkajian pasien baru/lama saat datang, melakukan konsultasi dengan dokter, membutuhkan tindakan perawatan, menunggu obat, hingga pasien selesai melakukan pengobatan rawat jalan.
Keberlangsungan sejak awal dan akhir serta berbagai faktor yang berkontribusi dalam pemberian layanan di instalasi rawat jalan akan memengaruhi kepuasan dan mutu pelayanan rumah sakit X. Kenyataannya di instalasi rawat jalan $\mathrm{RS} \mathrm{X}$, masih banyak kondisi pasien yang sejak awal datang hingga proses akhir kurang mendapat perhatian dan pelayanan yang optimal.

Kondisi pelayanan rawat jalan di beberapa negara kurang mendapat perhatian penuh seperti halnya pelayanan rawat inap. Hal ini dilihat dari minimnya peran konsultan dokter maupun perawat, sedikitnya waktu karena antrian pasien menunggu, minimnya komunikasi para tenaga medis, dan kurangnya pelatihan bagi tenaga kesehatan terkait pelayanan di instalasi rawat jalan (McKee \& Waghorn, 2000). Hal ini juga terjadi di instalasi rawat jalan RS X. Hasil observasi dan wawancara dengan kepala ruang dan instalasi rawat juga menegaskan bahwa kualitas pelayanan belum memberi kepuasan kepada pasien, terlebih pemberian asuhan keperawatan oleh perawat. Maka, sangat penting untuk melakukan optimalisasi pengelolaan asuhan keperawatan di instalasi rawat jalan sehingga akan tercipta mutu pelayanan yang berkualitas, prima, dan profesional.

\section{METODE}

Metode yang dilakukan ialah implementasi agen pembaharuan dengan menggunakan pendekatan studi pilot di instalasi rawat jalan. Peneliti bertindak sebagai agen pembaharu terkait optimalisasi pengelolaan asuhan keperawatan rawat jalan. Kegiatan ini berlangsung sejak 17 Oktober 2017 sampai dengan 17 November 2017. Kegiatan ini melibatkan Kepala Bidang Keperawatan, Kepala Seksi Asuhan Keperawatan, Kepala Instalasi Rawat Jalan, Kepala Ruang Rawat Jalan, Kepala Bagian Informasi dan 
Teknologi, dan perawat pelaksana di instalasi rawat jalan. Proyek ini diawali dengan melakukan analisis situasi pendekatan SWOT (strength, weakness, opportunity, threat), identifikasi masalah, penentuan prioritas masalah, analisis masalah dengan metode fish bone, dan penyelesaian masalah melalui pendekatan PDCA (plan, do, check, action).

Pengkajian awal dilakukan melalui metode observasi, survei, dan wawancara terstruktur. Metode pengumpulan data pada survei menggunakan dua jenis kuesioner tentang asuhan keperawatan. Kuesioner terdiri atas 12 pertanyaan (peran kepala ruangan) dan 28 pertanyaan (persepsi perawat tentang asuhan keperawatan di instalasi rawat jalan). Kuesioner dibagikan kepada seluruh perawat pelaksana di instalasi rawat jalan (28 orang). Kuesioner dimodifikasi berdasarkan peran kepala ruang dan perawat sebagai pemberi asuhan dan terkait uraian aktivias perawat rawat jalan sehari-hari. Pengumpulan data dilakukan melalui metode observasi menggunakan lembar observasi kegiatan perawat di instalasi rawat jalan. Pengumpulan data awal melalui wawancara yang dilakukan kepada Kepala Bidang, Kepala Seksi Asuhan Keperawatan, Kepala Ruang rawat jalan menggunakan instrumen panduan wawancara yang dibuat berdasarkan pendekatan fungsi manajemen Planning-Organizing-Staffing-ActuatingControlling (POSAC).

Pertimbangan etik dari studi pilot ini berada dalam bentuk persetujuan awal dari pembimbing klinik dan akademik terkait kuesioner, izin dari Kepala Instalasi, serta kesediaan perawat terlibat dalam kegiatan di instalasi rawat jalan. Data responden juga dirahasiakan karena kuesioner hanya melampirkan inisial perawat. Identifikasi akar masalah menggunakan analisis fish bone yang memunculkan masalah pengelolaan asuhan keperawatan rawat jalan yang belum optimal. Akar masalah ini selanjutnya akan diintervensi sesuai dengan perencanaan yang telah ditetapkan. Penyelesaian masalah dilakukan dengan startegi PDCA.

PDCA merupakan metode ilmiah yang memungkinkan untuk melakukan semua aktivitas berkualitas melalui perencanakan potensi penyebab dan resolusi setelah menentukan masalah (plan); melaksanakan rencana aksi (do); memeriksa hasilnya (check); dan mengoreksi tindakantindakan yang telah dilakukan, kemudian mengarahkannya kepada perencanaan selanjutnya (acting). Pengevaluasian tindakan dilakukan dengan wawancara terstruktur kepada perawat terkait proses dan pelaksanaan pemecahan masalah yang telah dilakukan, dan observasi dokumen rekam medis pasien. Kuesioner yang juga dibagikan kepada perawat dianalisis dengan program statistik sehingga menghasilkan tabel distribusi deskripsi. Hasil dari evaluasi dibentuklah rencana tindak lanjut yang telah disepakati oleh Kepala Bidang, Kepala Seksi Asuhan Keperawatan, dan Kepala Ruang Rawat Jalan.

\section{HASIL}

\section{Pengkajian Awal}

Setiap pasien berobat ke rawat jalan akan menjalani beberapa tahap. Prosesnya dimulai dengan pengambilan nomor antrian, menunggu di ruang tunggu, pemeriksaan oleh perawat, pemeriksaan oleh dokter, penyerahan berkas pasien setelah keluar dari ruang dokter (resep/ surat kontrol/ pemeriksaan penunjang/rujukan), dan hingga tahap terakhir pasien pulang dengan membawa obat dari rawat jalan atau ke rawat inap.

Pada tahap yang dijalani pasien, perawat rawat jalan berperan pada tahap pemeriksaan di ruang tunggu, ruang dokter, 
dan kemudian penyerahan setelah keluar dari ruang dokter. Tiga titik pada tahap yang menjadi saat perawat dalam memberikan asuhan keperawatan kepada pasien.

Di lapangan didapati kondisi perawat tidak memahami peran yang seharusnya dilakukan sebagai seorang pemberi asuhan keperawatan di instalasi rawat jalan. Idealnya, perawat melakukan pengkajian keperawatan sejak pasien datang ke meja perawat, menegakkan diagnosis serta menyiapkan berkas administrasi, intervensi terkait keluhan, melakukan implementasi baik tindakan mandiri maupun kolaborasi bersama dokter, dan melakukan evaluasi sebelum pasien meninggalkan rumah sakit.

Pada hasil kuesioner didapati $60,7 \%$ perawat jarang memahami uraian tugas sebagai perawat di instalasi rawat jalan. Hal ini didukung oleh pernyataan perawat bahwa tugas sebagai perawat hanya mengelola administrasi seperti menyiapkan berkas pasien, memanggil pasien, dan melengkapi rekam medis. Kepala ruangan menegaskan uraian tugas belum dijelaskan kepada setiap perawat sesuai dokumen yang telah ditetapkan dan diakui perawat kurang memahami uraian tugas dan kontribusi dalam pencapaian visi rumah sakit. Hal ini pun disebabkan instalasi rawat jalan tidak memiliki visi misi ruangan.

Pengkajian yang dilakukan kepada pasien baru/lama maupun pasien rujukan juga belum optimal. Data diperoleh $32,1 \%$ perawat menyatakan bahwa pelaksanaan pengkajian pasien di instalasi rawat jalan jarang diisi dengan lengkap. Perawat hanya melakukan pengukuran tensi darah dan jarang mengkaji keluhan dan berinteraksi melalui komunikasi terapeutik dengen pasien. Dalam hal dokumentasi, 53,6\% pengkajian keperawatan juga tidak dilakukan karena formulir pengkajian tidak sistematis, tidak ada tersedia petunjuk teknik, dan tidak pernah dilakukan sosialisasi pentingnya pengkajian pasien pada pelayanan keperawatan. Penyebab lainnya ialah koordinasi dengan rekam medis belum terlaksana dengan baik karena pengiriman rekam medis sering terlambat $(50 \%)$ dan rekam medis pasien yang sering dicetak dua atau lebih/ double medical record $(75.5 \%)$.

Tabel 1. Pelaksanaan asuhan keperawatan di RS $X$

\begin{tabular}{llrrr}
\hline No. & $\begin{array}{c}\text { Asuhan } \\
\text { Keperawatan }\end{array}$ & Pernah & Jarang & $\begin{array}{c}\text { Tidak } \\
\text { Pernah }\end{array}$ \\
\hline 1. & Pengkajian & $35,1 \%$ & $46,4 \%$ & $17,9 \%$ \\
2. & Diagnosis & $53,5 \%$ & $28,6 \%$ & $17,9 \%$ \\
3. & Intervensi & $35,7 \%$ & $42,9 \%$ & $21,4 \%$ \\
4. & Implementasi & $46,5 \%$ & $46,4 \%$ & $7,1 \%$ \\
5. & Evaluasi & $35,7 \%$ & $42,9 \%$ & $21,4 \%$ \\
\hline
\end{tabular}

Berdasarkan Tabel 1 didapati hasil bahwa perawat jarang melakukan pengkajian keperawatan (46,4\%). Perumusan diagnosis jarang dilakukan $(28,6 \%)$ dan tidak pernah $(17,9 \%)$ melakukan penegakan diagnosis maupun masalah keperawatan dan SOAP jarang diisi karena kurang memahami penulisan yang tepat dengan proses keperawatan. Didapati data $42,9 \%$ perawat jarang melakukan intervensi keperawatan di instalasi rawat jalan. Hal ini disebabkan rutinitas administrasi jarang diberi informasi tentang proses keperawatan dan persepsi perawat bahwa intervensi keperawatan hanya untuk rawat inap.

Implementasi keperawatan dapat dilakukan berupa tindakan mandiri perawat, kolaborasi, dan edukasi. Data menyajikan $46,4 \%$ perawat tidak pernah melakukan edukasi di instalasi rawat jalan. Perawat 
menyatakan pikiran mereka terfokus untuk penyelesaian berkas-berkas, sistem informasi rumah sakit generic open source (SIMRS GOS), dan antrean pasien sehingga disadari kurang untuk berkomunikasi/interaksi, bahkan memberikan edukasi kepada pasien. Evaluasi keperawatan juga tidak dilakukan karena perawat harus meng-input data, memanggil pasien selanjutnya dan melakukan pemilihan lembaran rawat jalan. Evaluasi secara terdokumentasi dari proses asuhan keperawatan juga minim. Didapati perawat jarang melakukan pendokumentasian SOAP dengan lengkap $(42,9 \%)$.

Menurut $46,4 \%$ perawat, IRJ RS X kekurangan tenaga di instalasi rawat jalan karena kunjungan \pm 1.000 /hari. Hal ini juga ditegaskan kepala ruangan, bahwa setiap perawat harus lembur minimal $4 \mathrm{kali} /$ minggu. Menurut perawat IRJ, kurang optimalnya pelayanan keperawatan, interaksi dengan pasien, dan pelaksanaan dokumentasi disebabkan oleh ketidaksesuaian jumlah tenaga, pendokumentasian manual yang menyita waktu \pm 10 menit, dan budaya dokter yang tidak mandiri saat pemeriksaan pasien (pendampingan penuh oleh perawat). Oleh karena itu, diperlukan penelaahan lebih lanjut terkait kebutuhan tenaga serta faktor untuk pengoptimalan pengelolaan asuhan keperawatan rawat jalan.

Masalah yang ada diprioritaskan dengan teknik kriteria sampel menghasilkan prioritas masalah utama di instalasi rawat jalan, yaitu belum optimalnya pengelolaan asuhan keperawatan di Instalasi Rawat Jalan RS $X$. Penetapan masalah belum optimalnya pengelolaan asuhan keperawatan di instalasi rawat jalan menjadi prioritas karena melihat waktu studi pilot yang terbatas, penyelesaian faktor-faktor yang mendukung pengelolaan asuhan keperawatan lebih memungkinkan untuk ditindaklanjuti daripada masalah kebutuhan SDM, asuhan keperawatan belum pernah mendapat perhatian khusus dari rumah sakit, dan prioritas masalah asuhan keperawatan di instalasi rawat jalan akan menjadi awal untuk melakukan evaluasi mutu pelayanan keperawatan di instalasi rawat jalan.

Penentuan penyebab masalah menggunakan metode fish bone. Pencarian akar penyebab masalah yang sudah ditetapkan disajikan pada diagram 1.

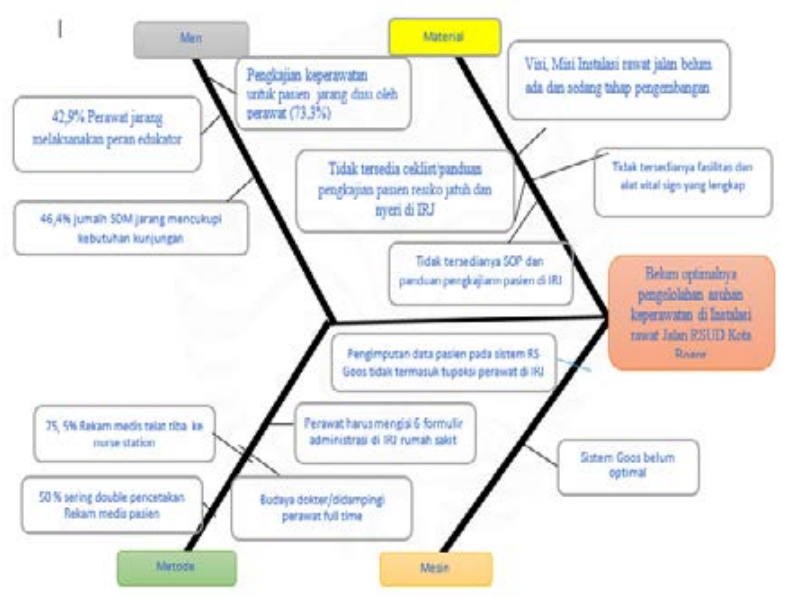

Diagram 1. Penetapan akar masalah ketidakoptimalan pengelolaan asuhan keperawatan di instalasi rawat jalan dengan analisis fish bone

Manajemen keperawatan meliputi lima fungsi utama, yaitu perencanaan, pengorganisasian, pengaturan staf, pengarahan, dan pengendalian aktivitas unit keperawatan. Seorang manajer perawat melaksanakan fungsi manajemen untuk memastikan kualitas pelayanan keperawatan yang diterima pasien (Marquis \& Huston, 2012). Tahap implementasi diawali dengan identifikasi masalah yang relevan untuk diselesaikan, melakukan konsolidasi, dan negosiasi bersama Bagian Keperawatan serta Kepala Ruang. Dasar pelaksanaan dilakukan sesuai rencana aksi yang dibuat sesuai dengan kelima fungsi manajemen. Peran dan kesepakatan dengan Kepala Bidang Keperawatan, Kepala Seksi Asuhan, dan Kepala Ruang Rawat Jalan menjadi hal 
yang penting dalam proses implementasi. Implementasi yang dilakukan dengan strategi dalam pemecahan masalah ialah siklus plan, do, check, and acting (PDCA). Siklus PDCA juga mengakomodasi fungsifungsi manajemen dalam upaya pencapaian pengoptimalan pengelolaan asuhan keperawatan (Huber, 2010).

\section{Perencanaan (Plan)}

Perencanaan (plan) diawali dengan menetapkan perancangan visi misi instalasi rawat jalan, uraian tugas perawat, standar operasional proseduryang mendukung asuhan keperawatan seperti penerimaan pasien rawat jalan, pengkajian pasien, pengisian format pengkajian, pendokumentasian SOAP, dan standar asuhan keperawatan di instalasi rawat jalan serta sosialisasi draf bila sudah disetujui oleh rumah sakit. Perencanaan koordinasi dengan kepala bidang IT dan rekam medis juga dilakukan dan pada tahap ini dilakukan koordinasi dan diskusi dengan Kabid Keperawatan, Kasie Askep, Ka Ins, dan Karu rawat jalan. Persiapan alat, ruangan, ATK serta kajian literatur juga dilakukan dan dikoordinasikan sebelum diintervensi.

\section{Pelaksanaan (Do)}

Pelaksanaan (do) diawali brainstorming telah dilakukan untuk visi misi dan uraian tugas perawat rawat jalan. Penyusunan petunjuk pengkajian formulir keperawatan, SOP pengkajian, dan pendokumentasian keperawatan sudah disosialisasikan. Hal ini dilakukan untuk memenuhi kebutuhan perawat terkait alur dan format yang lebih sistematis dan mencakup komponen proses keperawatan. Pembuatan standar asuhan keperawatan rawat jalan dengan penyusunan berdasarkan sepuluh masalah keperawatan yang sering ditemukan di instalasi rawat jalan dan memungkinkan dilakukan. Sosialisasi juga telah dilakukan sesuai perencanaan di awal dan mendapat dukungan rumah sakit.

\section{Pengevaluasian (Control)}

Pengevaluasian pelaksanaan terdiri atas evaluasi struktur, proses, dan hasil. Evaluasi hasil dari format yang telah dibuat dan disosialisasikan mendapat respons yang positif dari rumah sakit.

Evaluasi terkait pelaksanaan pengelolaan asuhan dilakukan dengan observasi dokumen, pemberian pemicu contoh kasus, dan praktik pengisian formulir dan kuesioner persepsi perawat setelah sosialiasi. Pada hasil sosialisasi yang dilakukan didapati beberapa kondisi serta data.

Evaluasi hasil observasi di lapangan sudah dilakukan dan dinilai ada perbaikan. Namun, implementasi seperti pemberian edukasi masih minim ( 3 dari 22 orang perawat yang dinas pada shift yang sama setiap pagi). Pada hasil wawancara dengan perawat, pemberian informasi penting untuk kembali diingatkan dan harapannya ada informasi yang terus diberikan secara konsisten setiap pagi.

Pada hasil telusur 66 dokumen rekam medis pasien (formulir pengkajian dan catatan keperawatan rawat jalan), hanya 15 rekam medis pasien yang tidak lengkap pada catatan keperawatan. Bagian yang tidak terisi pada A (assessment) dan P (plan).

Gambaran pengetahuan perawat tentang lima proses keperawatan sebelum dan sesudah sosialiasi proses asuhan keperawatan dapat digambarkan pada Diagram 2. Namun, untuk pelaksanaan pada tahap implementasi terkadang masih sulit dilaksanakan saat antrean pasien masih panjang. 


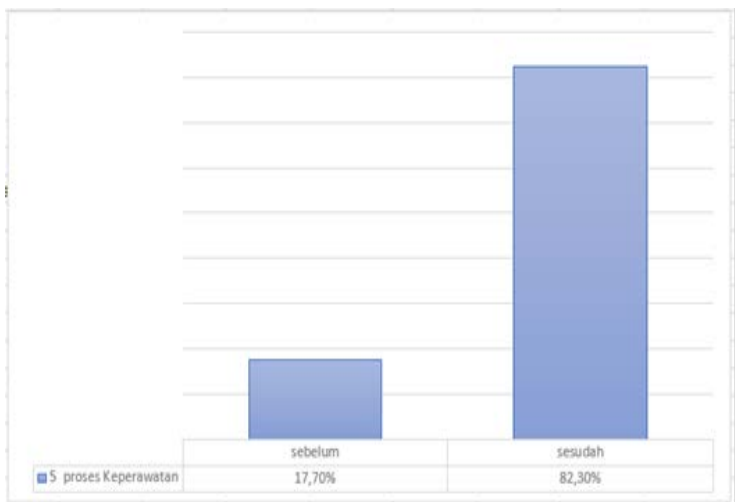

Diagram 2. Gambaran pengetahuan perawat sebelum dan sesudah sosialisasi proses asuhan

keperawatan lima proses keperawatan $(n=28)$

Evaluasi akhir dari rangkaian kegiatan yang sudah diakukan, yaitu menyimpulkan persepsi perawat tentang faktor-faktor yang memengaruhi pengoptimalan asuhan keperawatan dan dapat dilihat pada Diagram 3 berikut ini.

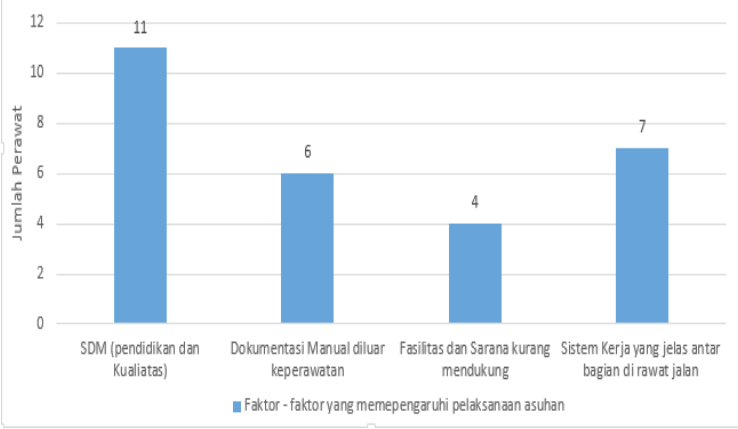

Diagram 3. Faktor yang memengaruhi pelaksanaan asuhan keperawatan menurut persepsi perawat di instalasi rawat jalan $\mathrm{RS} X(\mathrm{n}=28)$

Diagram 3 menunjukkan hasil evaluasi bersama perawat pelaksana yang menjadi faktor dalam pelaksanaan asuhan keperawatan yang optimal di instalasi rawat jalan, yaitu 11 perawat menyatakan faktor sumber daya manusia, 7 perawat menyatakan faktor sistem kerja yang jelas antarbagian di instalasi rawat jalan, 6 menyatakan adanya faktor dokumentasi manual di luar keperawatan, dan 4 perawat menyatakan faktor fasilitas dan sarana kurang memadai. Rencana tindak lanjut akan diadakan evaluasi dari bidang keperawatan terkait pengoptimalan asuhan keperawatan di instalasi rawat jalan dengan monitoring oleh kepala ruangan dan telusur dokumen yang diadakan setiap akhir bulan.

\section{DISKUSI}

Beberapa negara berupaya menjaga kualitas asuhan keperawatan karena memandang asuhan keperawatan sebagai standar proses dalam pelaksanaan praktik keperawatan, tetapi tidak dapat dihindari dalam pelaksanaannya sering ada kendala dan tidak sesuai dengan teori yang diharapkan (Hagos et al., 2014; Baraki et el., 2017; Hariyati et al., 2016). Hal ini disebabkan oleh antrean pasien meningkat, komunikasi para tenaga medis minim, dan kurangnya pelatihan bagi tenaga kesehatan terkait pelayanan di instalasi rawat jalan (McKee \& Waghorn, 2000).

Hal ini juga terjadi di RS X khususnya di instalasi rawat jalan. Rawat jalan yang merupakan bagian pelayanan rumah sakit dengan akses pemberian pelayanan singkat \pm 15 menit setiap pasien (Divisi Pelayanan Medik dan Keperawatan, 2016) sering dikaitkan dengan sistem antrean yang panjang, hanya pengobatan singkat, dan minimnya interaksi dalam pemberian asuhan keperawatan maupun medis.

Asuhan keperawatan merupakan bagian dari suatu sistem pelayanan yang terintegrasi dengan para profesional di bidang pelayanan kesehatan dan tingkat pelayanan yang akan membangun suatu kontinuitas pelayanan. Maksud dan tujuannya adalah menyelaraskan kebutuhan asuhan pasien dengan pelayanan yang tersedia di rumah sakit, mengoordinasikan pelayanan, kemudian merencanakan pemulangan dan tindakan selanjutnya. Hasilnya ialah peningkatan mutu asuhan pasien dan efisiensi penggunaan sumber daya yang tersedia di rumah sakit (KARS, 2017). Oleh karena 
itu, diperlukan kesinambungan dan sistem layanan terintegrasi optimal yang dirancang sejak pasien masuk hingga meninggalkan rumah sakit.

Di Instalasi Rawat Jalan RS X, diakui pengelolaan asuhan keperawatan belum optimal karena berbagai faktor yang ditemukan. Faktor yang ditemukan berasal dari internal dan eksternal rumah sakit. Faktor internal berupa alur kerja, material, kualitas sumber daya manusia, serta fasilitas yang dimiliki. Kondisi hampir sama juga ditemukan di rumah sakit pemerintah di Addis Ababa, Ethiopia yang mengidentifikasi adanya faktor organisasi, faktor pasien, tingkat pengetahuan, konflik pelaksanaan peran, dan keterampilan sumber daya manusia, terutama perawat yang sangat berpengaruh terhadap kualitas asuhan keperawatan (Aseratie, Murugan, \& Molla, 2014). Hal ini dapat terjadi karena perawat sebagai profesi yang memberikan asuhan secara holistik dipengaruhi oleh berbagai tingkat kebutuhan pasien, kondisi fasilitas dan sarana di rumah sakit, alur, serta kondisi lainnya. Oleh karena itu, perawat sebagai memerlukan dukungan berbagai pihak agar pemberian asuhan kepada pasien tidak terhambat.

Kualitas asuhan keperawatan dapat menggambarkan keberhasilan RS dalam memberikan pelayanan dan hal ini bergantung pada pengelolaan sumber daya manusia guna mencapai visi, misi, dan tujuan organisasi. Manajemen sumber daya manusia menjadi keputusan strategis dalam sebuah rumah sakit organisasi (Mathis \& Jackson, 2010; Marquis \& Huston, 2012). Tujuan organisasi yang ingin dicapai membutuhkan peran manajer yang berkualitas dalam mengelolah sumber daya manusia yang dimiliki. Beberapa ahli menyebutkan peran manajer diperlukan dalam mengelola sumber daya manusia dalam hal desain pekerjaan, pelatihan dan pengembangan, manajemen kinerja, hubungan personal, dan komunikasi dengan berbagai sektor (Meng \& Boyd, 2017). Seorang manajer harus mampu menentukan perencanaan pengembangan sumber daya manusia (Hariyati, 2014).

Pengembangan sumber daya manusia seperti pelatihan dan pendidikan dapat digunakan untuk meningkatkan pengetahuan staf, keterampilan, dan sikap staf (Gillies, 2006). Faktor sumber daya manusia dapat dinilai dari status demografi, tingkat pengetahuan (khususnya terkait proses keperawatan), keterampilan, pengalaman, motivasi, kepuasaan kerja, stres lingkungan kerja, dan kesadaran perawat sendiri akan kualitas pelayanan dalam di fasilitas kesehatan tersebut (Shewangizaw \& Mersha, 2015). Karakteristik sumber daya manusia dari tingkat pendidikan sangat berpengaruh. Hal ini didukung pengamatan bahwa status pendidikan memiliki hubungan signifikan secara statistik terhadap asuhan keperawatan kepada pasien. Perawat dengan tingkat pendidikan sarjana pastinya memiliki dan memberikan asuhan keperawatan yang lebih baik daripada perawat di bawah pendidikan diploma ( $p<0,001)$ (Hagos et al., 2014).

Perawat dengan tingkat pendidikan sarjana 6,972 kali lebih mungkin menerapkan proses keperawatan daripada perawat yang memiliki pendidikan diploma. Perawat tanpa dasar teori yang konsisten 95,1\% lebih kecil kemungkinannya untuk menerapkan proses keperawatan daripada perawat yang memiliki pemahaman teori yang baik (Aseratie, Murugan, \& Molla, 2014; Hariyati \& Safril, 2018; Hariyati et al., 2017). Hal ini didukung oleh penelitian yang menyatakan tingkat pendidikan yang lebih tinggi akan berdampak terhadap implementasi asuhan keperawatan 8,78 kali lebih baik daripada perawat yang kurang pengetahuan secara akademik (Shewangizaw \& Mersha, 2015). Sumber daya manusia, khususnya perawat di IRJ 
RS X 90\% berlatar pendidikan diploma dan $10 \%$ SPK. Bila melihat kemajuan teknologi, tuntutan pasien, akreditasi, dan semakin ketatnya persaingan saat ini, kualitas perawat berdasakan tingkat pendidikan menjadi hal yang penting untuk diperhatikan. Seperti yang dikemukakan oleh Hariyati (2014), pendidikan berkelanjutan merupakan dasar pengembangan staf sebagai upaya peningkatan kemampuan perawat baik dalam segi pengetahuan, keterampilan, maupun sikap dan perilaku.

Pelatihan juga mampu meningkatkan pengetahuan, perbaikan sikap, koping dan kesiapan perawat saat melakukan praktik keperawatan (Kim \& Hwang, 2014). Hal ini penting ditekankan lagi, mengingat tuntutan peningkatan pelayanan akreditasi tiap tahun semakin tinggi dan telah disebutkan bahwa pemberi asuhan profesional hanya perawat dnegan latar pendidikan ners (Komite Akreditasi Rumah Sakit, 2017). Jadi, diperlukan upaya dari kepala ruangan dan manajer keperawatan untuk merencanakan dan memotivasi staf untuk menjalani pendidikan tingkat lanjut, mengikuti pelatihan terkait kompetensi keperawatan, dan mencari alternatif berupa pelatihan internal melalui briefing pagi guna mengoptimalkan asuhan keperawatan kepada pasien di instalasi rawat jalan.

Faktor lain yang dapat memengaruhi kualitas asuhan keperawatan ialah beban kerja di ruang tersebut. Di IRJ RS X beban kerja dikaitkan dengan kunjungan, jumlah tenaga keperawatan, dan jenis pekerjaannya. Persepsi $46,4 \%$ perawat jumlah tenaga tidak sesuai dengan jumlah kunjungan setiap harinya dan $64,9 \%$ perawat lebih banyak melakukan tugas administrasi daripada tugas pokok keperawatan. Saat observasi, mayoritas tugas perawat di instalasi rawat jalan berada pada pekerjaan di luar keperawatan (non nursing job). Menurut Komite Akreditasi
Rumah Sakit (2017) dan Hariyati (2014), faktor yang harus dipertimbangkan dalam memproyeksikan atau mengestimasi kebutuhan staf tidak lepas dari visi misi rumah sakit, perpaduan antara pasien yang dilayani oleh rumah sakit dan kompleksitas dan kebutuhan pasien, jenis pelayanan yang disediakan oleh rumah sakit, dan teknologi yang digunakan oleh rumah sakit dalam asuhan pasien. Seharusnya pelayanan observasi kompleksitas pasien di instalasi rawat jalan dapat dikoordinasi dengan waktu 15 menit. Akan tetapi, saat diobservasi setiap pasien berinteraksi dengan tim medis (dokter dan perawat) hanya \pm 3 menit dan waktu perawat lebih banyak untuk mempersiapkan administrasi dan melaksanakan tugas di luar keperawatan.

Hal ini juga ditemukan pada salah satu penelitian yang dilakukan di Turki. Dikatakan bahwa perawat tidak melakukan asuhan keperawatan karena lebih banyak tuntutan tugas perawat untuk melaksanakan pengobatan dan registrasi pasien (Aslan et al., 2016). Beban kerja yang meningkat di luar tugas keperawatan menyebabkan perawat tidak punya cukup waktu untuk melakukan tugasnya. Manajer perlu mengorganisasikan tugas dan fungsi perawat sesuai uraian tugas yang telah ditetapkan. Manajer tingkat pertama, yaitu kepala ruangan di instalasi rawat jalan sebaiknya menjalankan peran kepemimpinan dan fungsi manajemen dan menetapkan model asuhan pasien. Pengelolaan asuhan keperawatan model tim menjadi alternatif untuk memaksimalkan praktik keperawatan di instalasi rawat jalan. Asuhan keperawatan tim akan mampu mengakomodasi pelayanan kepada pasien serta meningkatkan kerja sama dan komunikasi kepada sekelompok pasien meskipun jumlah tenaga keperawatan belum mencukupi (Marquis \& Huston, 2012). 
Perawat di instalasi rawat jalan bertugas sebagai pemberi asuhan keperawatan berkaitan erat dengan pendokumentasian. Tugas pendokumentasian dan sistem pelaporan yang diharuskan oleh rumah sakit menjadi faktor yang dapat berpengaruh terhadap pemberian asuhan keperawatan. Pendokumentasian menjadi hal yang penting dalam rangkaian asuhan keperawatan karena dapat menggambarkan kualitas pelayanan keperawatan di rumah sakit (Siswanto, Hariyati, \& Sukihananto, 2013). Dewi, Yetti, \& Ayubi (2013) menyatakan dokumentasi keperawatan penting karena menjadi kerangka akuntabilitas perawat dan memerlukan supervisi dari kepala ruangan.

Pendokumentasian menempati posisi mayoritas dalam tugas sehari-hari perawat dan bagian integral dalam keberlangsungan pelayanan kepada pasien serta penting untuk dilengkapi. Ketidaklengkapan dokumentasi asuhan keperawatan ada hubungannya dengan masa kerja, pelatihan, dan beban kerja yang tinggi (Siswanto, Hariyati, \& Sukihananto, 2013). Di RS X didapati kondisi tugas pendokumentasian untuk administrasi rumah sakit di luar catatan keperawatan cukup menyita waktu dan sumber daya. Hal ini disebabkan kurang optimalnya penggunakan sistem informasi rumah sakit yang sudah ada serta pengelolaan maupun supervisi yang dilakukan kepala ruangan. Minimnya dokumentasi keperawatan terstandar berbasis elektronik menyebabkan tersitanya waktu perawat saat pengkajian, penegakan diagnosis, dan tujuan, implementasi, serta evaluasi (Häyrinen, Lammintakanen, \& Saranto, 2010; Dwisatyadini, Hariyati, \& Afifah, 2018).

Teknologi informasi dan komunikasi di bidang kesehatan akan meningkatkan perawatan yang berpusat pada pasien, meningkatkan kualitas layanan rumah sakit, menjadi media pendidikan profesional kesehatan maupun pasien, dan dapat mengefektifkan pemberian asuhan keperawatan yang diberikan oleh perawat (Rouleau, Gagnon, \& Côté, 2015). Penting dilakukan pengembangan dokumentasian keperawatan berbasis elektronik guna meningkatkan efektivitas dan efisiensi pelayanan keperawatan, seperti penelitian yang telah dilakukan dan menghasilkan kesimpulan bahwa penggunaan dokumentasi keperawatan menggunakan sistem SIMPRO akan memperbaiki kualitas dokumentasi $(p=0,0001)$ dan efisiensi $(p=0,0001)$ (Hariyati et al., 2016).

Selain pengefektifan dokumentasi berbasis elektronik diperlukan juga peran seorang manajer dalam mengoptimalkan sistem dokumentasian yang dilakukan (Fagerström, Lønning, \& Andersen, 2014). Di RS X yang telah dilakukan ialah koordinasi dengan Kepala Bidang Keperawatan dan Kasie Asuhan untuk merevisi sistem pendokumentasian manual dan akan rencana pengembangan pendokumentasian berbasis elektronik pada tahun 2018. Saat ini hal yang dilakukan masih berada pada tahap melakukan pembaruan dalam sistem pencatatan administrasi pasien, pelaporan harian/bulanan, penghapusan beberapa kolom pada buku administrasi, dan penghapusan beberapa formulir manual di instalasi rawat jalan untuk dialihkan ke checklist di sistem pendataan di setiap komputer instalasi rawat jalan.

Peran manajer juga memengaruhi hasil akhir pemberian asuhan keperawatan. Peran manajer sebagai sumber informasi dan melaksanakan fungsi manajemen dalam pelaksanaan asuhan yang dilakukan perawat pelaksana sangat diperlukan dan akan berdampak pada kepuasan kerja perawat (Cummings et al., 2010). Peran pengarahan dilaksanakan untuk memotivasi, membina komunikasi organisasi, menangani konflik, 
memfasilitasi kerja sama dalam pemberian pelayanan, dan berdampak terhadap kepuasan kerja karyawan (Marquis \& Huston, 2012). Perawat membutuhkan motivasi/ dukungan positif secara konsisten yang diberikan oleh atasan, teman sejawat dalam proses pelaksanaan asuhan keperawatan (Hagos et al., 2014). Hal ini didukung oleh penelitian yang dilakukan Aseratie, Murugan, \& Molla (2014) yang menyatakan bahwa suasana stres di tempat kerja 99\% menyebabkan kemungkinan proses keperawatan tidak dapat terlaksana daripada suasana kerja yang menyenangkan.

Kepuasan kerja perawat dipengaruhi oleh manajemen organisasi, pendapatan, tekanan di lingkungan kerja, serta beban kerja (Mokoka, Oosthuizen, \& Ehlers, 2010). Upaya yang dilakukan di instalasi rawat jalan RS X ialah meningkatkan motivasi setiap paginya dengan mengoptimalkan briefing pagi. Kepala ruangan meningkatkan motivasi dengan mengarahkan staf pada visi misi rumah sakit dan ruangan serta memberikan semangat dengan menyebutkan yel-yel secara bersama-sama dan bergantian setiap paginya. Selain itu, kepala instalasi dan kepala ruangan memberikan reward kepada staf yang mampu mengingat bahkan mengetahui sosialiasi terkait informasi, SOP, maupun hal lainnya di briefing pagi. Hal ini dilakukan untuk membangun motivasi kerja serta suasana yang nyaman kepada perawat. Reward yang diberikan mampu membangun kekompakan, hubungan intrapersonal, dan lingkungan kerja yang positif serta tidak lepas dari kemampuan komunikasi pemimpin (Whitehead, Weiss, \& Tappen, 2010).

Kepala ruangan IRJ RS X sebaiknya mengelompokkan kualifikasi perawat sesuai kompetensi dan dengan kriteria kebutuhan pasien di setiap ruangan poliklinik yang ada. Kepala ruangan mengklarifikasi jadwal pasien yang membutuhkan tindakan dan menempatkan perawat yang tepat sesuai kompetensi. Selain itu, kepala ruangan rawat jalan RS $X$ juga harus mampu mengelolah penjadwalan dinas perawat dengan baik karena jam kerja yang panjang (long shift) dengan frekuensi intens akan memengaruhi kualitas asuhan keperawatan dan kepuasan kerja (Stimpfel, Sloane, Aiken, 2012). Pengelolaan dengan perbandingan rasio perawat dan kunjungan pasien juga harus diperhatikan guna mengoptimalkan asuhan yang diberikan kepada pasien (Nantsupawat et al., 2011; Hagos et al., 2014). Pengelolaan dilakukan dengan menempatkan perawat dengan jumlah serta kompetensi yang sesuai dan tingkat kebutuhan pasien yang membutuhkan perawatan/pengobatan saja (Mobasher, 2011). Diperlukan pengelolaan tugas dan fungsi perawat dengan memaksimalkan sumber daya yang dimiliki organisasi.

\section{SIMPULAN}

Pengelolaan asuhan keperawatan mencakup berbagai faktor. Faktor dari organisasi rumah sakit berupa dukungan manajemen rumah sakit dalam penyediaan fasilitas sarana prasaran yang mendukung pelayanan keperawatan, sistem/alur kerja bagian lainnya, serta sistem informasi rumah sakit. Faktor yang berperan besar ialah tenaga keperawatan sebagai pemberi asuhan keperawatan kepada pasien. Faktor tingkat pendidikan, keterampilan perawat, kepuasan kerja serta keseimbangan rasio perawat dengan pasien harus dipertimbangkan. Berbagai hal ini memengaruhi kualitas asuhan keperawatan yang berdampak pada mutu pelayanan dan keselamatan pasien. Oleh karena itu diperlukan peran manajer dalam mengoptimalkan peran dan fungsi manajemen dalam pengelolaan asuhan keperawatan. Rekomendasi manajer seharusnya merencanakan peningkatan 
kualitas asuhan keperawatan melalui pengarahan pelayanan berdasarkan visi misi rumah sakit, peningkatan pendidikan staf, serta peningkatan motivasi tenaga keperawatan, dan koordinasi dengan sektor lain dalam pengadaan fasilitas dan sistem layanan guna efektivitas pelayanan keperawatan.

\section{DAFTAR PUSTAKA}

Aseratie, M., Murugan, R., \& Molla, M. (2014). Assessment of Factors Affecting Implementation of nursing process among nurses in selected Governmental Hospitals, Addis Ababa, Ethiopia; Cross Sectional Study. J Nurs Care, 3: 170.

Aslan, M., Karaaslan, A., Yildiz, A., Dogan, F., \& Evirgen, H. (2016). Workload of nurses and care left undone: Do we really care enough?. International Journal of Caring Sciences, 9(2): 596-602.

Baraki, Z., Girmay, F., Kidanu, K., Gerensea, H., Gezehgne, D., \& Teklay, H. (2017). A cross sectional study on nursing process implementation and associated factors among nurses working in selected hospitals of Central and Northwest zones, Tigray Region, Ethiopia. BMC Nurs, 16: 54.

Cummings, G. G., MacGregor, T., Davey, M., Lee, H., Wong, C. A., Lo, E., Muise, M., Stafford, E. (2010). Leadership styles and outcome patterns for the nursing workforce and work environment: A systematic review. Int J Nurs Stud, 47(3): 363-385.

Dewi, R., Yetti, K., \& Ayubi, D. (2008). Supervisi kepala ruangan berdasarkan kelengkapan pendokumentasian asuhan keperawatan. Jurnal Keperawatan Indonesia, 12(3): 187-192.

Divisi Pelayanan Medik dan Keperawatan. (2016). Pedoman pelayanan instalasi rawat jalan RS X. Bogor. Tidak dipublikasikan.

Dwisatyadini, M., Hariyati, R. T. S., \& Afifah, E. (2018). The effects of the application of SIMPRO on the completeness and time efficiency of nursing documentation in the outpatient instalation at Dompet Dhuafa Hospital Parung. IOP Conference Series: Materials Science and Engineering, 332(1): 012034.

Fagerström, L., Lønning, K., \& Andersen, M. H. (2014). The RAFAELA system: A workforce planning tool for nurse staffing and human resource management. Nurs Manag (Harrow), 21(2): 30-36.

Gillies, D. A. (2006). Nursing management: $A$ system approach (2nd edition). Boston: W.B. Saunders Company.

Hagos, F., Alemseged, F., Balcha, F., Berhe, S., \& Aregay, A. (2014). Application of nursing process and its affecting factors among nurses working in Mekelle Zone Hospitals, Northern Ethiopia. Retrieved from http://dx.doi. org/10.1155/2014/675212

Hariyati, R. T. S. (2014). Perencaaan, pengembangan dan utilisasi tenaga keperawatan. Jakarta: Rajawali Pers.

Hariyati, R. T. S., Igarashi, K., Fujinami, Y., Susilaningsih, S., Prayetni. (2017). Correlation between career ladder, continuing professional development and nurse satisfaction: A case study in Indonesia. International Journal of Caring Sciences, 10(3): 1490-1497.

Hariyati, R. T. S. \& Safril, S. (2018). The relationship between nurses' job satisfaction and continuing professional development. Enferm Clin, 28 suppl 1: 144-148.

Hariyati, R. T. S., Yani, A., Eryando, T., Hasibuan, Z., \& Milanti, A. (2016). The effectiveness and efficiency of nursing care documentation using the SIMPRO model. Int J Nurs Knowl, 27(3): 136-142. 
Häyrinen, K., Lammintakanen, J., \& Saranto, K. (2010). Evaluation of electronic nursing documentation-Nursing process model and standardized terminologies as keys to visible and transparent nursing. Int J Med Inform, 79(8): 554-564.

Huber, D. L. (2010). Leadership and nursing care management. Saunders Elsevier (Fourth Ed.). Missouri: Saunders Elsevier.

Kim, S., \& Hwang, W. J. (2014). Palliative care for those with heart failure: Nurses' knowledge, attitude, and preparedness to practice. Eur J Cardiovasc Nurs, 13(2): 124-133.

Komisi Akreditasi Rumah Sakit. (2012). Standar Akreditasi Rumah Sakit. Jakarta.

Komite Akreditasi Rumah Sakit. (2017). Standar Akreditasi Rumah Sakit Jilid 1. Jakarta: Komite Akreditasi Rumah Sakit.

Kumari, S. S. M. H. \& De, A. C. A. (2015). The nursing shortage impact on job outcome (the case in Sri Lanka). Journal of Competitiveness, 7(3): 75-94.

Manion, J. (2014). Every nurse a leader. Journal of Peri Anesthesia Nursing, 29(4): 320-323.

Marquis, B. L. \& Huston, C. J. (2012). Leadership and management tools for the new nurse: A case study approach. Wolters Kluwer Health/Lippincott Williams \& Wilkins.

Marquis, B. L. \& Huston, C. J. (2015). Leadership roles and management functions in nursing: Theory and application (8th edition). Canada: Lippincott Williams \& Wilkins.

Mathis, L. R., \& Jackson, J. H. (2010). Human resource management (Thirteenth Edition). Mason: South-Western Cengage Learning.

McKee, M., \& Waghorn, A. (2000). Why is it so difficult to organise an outpatient clinic?. Health Serv Res Policy, 5(3): 140-147.

Meng, X., \& Boyd, P. (2017). The role of the project manager in relationship management. International Journal of Project Management, 35(5): 717-728.

Miltner, R. S., Jukkala, A., Dawson, M. A., \& Patrician, P. A. (2015). Professional development needs of nurse managers. Journal of Continuing Education in Nursing, 46(6): 252-258.

Mobasher, A. (2011). Nurse scheduling optimization in a general clinic and an operating suite (disertasi). Faculty of the Department of Industrial Engineering, University of Houston, Houston, USA.

Mokoka, E., Oosthuizen, M. J., \& Ehlers, V. J. (2010). Retaining professional nurses in South Africa: Nurse managers' perspectives. Health SA Gesondheid, 15(1): Art. \#484, 9 halaman.

Nantsupawat, A., Srisuphan, W., Kunaviktikul, W., Wichaikhum, O. A., Aungsuroch, Y., \& Aiken, L. H. (2011). Impact of nurse work environment and staffing on hospital nurse and quality of care in Thailand. $J$ Nurs Scholarsh, 43(4): 426-432.

Rouleau, G., Gagnon, M. P., \& Côté, J. (2015). Impacts of information and communication technologies on nursing care: an overview of systematic reviews (protocol). Syst Rev, 4(1): 75.

Shewangizaw, Z., \& Mersha, A. (2015). Determinants towards implementation of nursing process. American Journal of Nursing Science, 4(3): 45-49.

Siswanto, L. M. H., Hariyati, R. T. S., \& Sukihananto. (2013). Faktorfaktor yang berhubungan dengan kelengkapan pendokumentasian asuhan keperawatan. Jurnal Keperawatan Indonesia, 16(2): 77-84.

Stimpfel, A. W., Sloane, D. M., \& Aiken, L. H. (2012). The longer the shifts for hospital 
nurses, the higher the levels of burnout and patient dissatisfaction. Health Aff (Milwood), 31(11): 2501-2509.

Westbrook, J. I., Duffield, C., Li, L., \& Creswick, N. J. (2011). How much time do nurses have for patients? a longitudinal study quantifying hospital nurses' patterns of task time distribution and interactions with health professionals. BMC Health Services Research, 11: 319.

Whitehead, D. K., Weiss, S. A., \& Tappen, R. M. (2010). Essentials of nursing leadership and management. Philadelphia: F.A. Davis Company. 